\title{
Modelling management process of key drivers for economic sustainability in the modern conditions of economic development
}

\author{
E.S. Pishchulina ${ }^{1, *}$ \\ ${ }^{1}$ South Ural State University, Chelyabinsk, Russia
}

\begin{abstract}
The text is about issues concerning the management of driver for manufacturing enterprise economic sustainability and manufacturing enterprise sustainability assessment as the key aspect of the management of enterprise economic sustainability. The given issues become topical as new requirements for the methods of manufacturing enterprise management in the modern conditions of market economy occur. An economic sustainability model that is considered in the article is an integration of enterprise economic growth, economic balance of external and internal environment and economic sustainability. The method of assessment of economic sustainability of a manufacturing enterprise proposed in the study allows to reveal some weaknesses in the enterprise performance, and untapped reserves, which can be further used to improve the economic sustainability and efficiency of the enterprise. The management of manufacturing enterprise economic sustainability is one of the most important factors of business functioning and development in modern market economy. The relevance of this trend is increasing in accordance with the objective requirements of the growing volumes of production and sale, the increasing complexity of economic relations, changing external environment of an enterprise.
\end{abstract}

\section{Introduction}

Economic sustainability management is one of the most significant drivers for modern businesses development in modern market economy. The relevance of this trend is increasing in accordance with the conditions of changing external environment.

The current state of the issue of enterprise economic sustainability management is a lack of a clear mechanism for monitoring the prospects of development of both the enterprise and the environment and individuals who are to make sound managerial decisions [14].

As to management methods, the current market tools cannot be considered fully formed. It is especially true for inter-firm relationships, as the interaction has not been worked out while necessary communication links have not been provided. Significant differences in setting goals to complete the tasks of individual enterprises complicate management decision-making aimed to harmonize common interests. Thus, it makes the lack of behavior management capabilities of individual objects of economic activity prominent [3].

Modern Russia's economy is characterized by a strong dependence on the world oil prices. The fall of these prices, which began in 2015 and continues up to this day led to a significant fall of the ruble and, consequently, to a sharp rise in prices and reduction of the purchasing power of the Russian population. In addition, economic sanctions imposed against Russia by many of European countries and the United States, forced to introduce responsive measures against these countries. All these factors have led to a sharp decline in the economic stability of Russian enterprises, and will continue to contribute to the prominent tendency towards bankruptcy and withdrawal from the market of those companies that are not able to adjust to changes in the external environment.

Therefore, under the circumstances, in order to make the company remain economically stable in the market, efficient and profitable it is sufficient to reveal the relationship. Also it is essential to determine the dependence of drivers for economic sustainability and to make adequate managerial decisions aimed to improve it [7].

\section{Theoretical framework and literature review}

The current state of economic stability of enterprise management problems can be represented as a lack of a clearly defined mechanism to ensure dynamic and effective monitoring of the long-term prospects for the development of both the manufacturing enterprise and the environment and to take adequate methodologically based managerial decisions.

Problems of economic sustainability of economic systems, economic development and growth are

Corresponding author: pishchulinaes@susu.ac.ru 
reflected in the works of such Russian scientists as L. Abalkin, I. Aleshin, A. Schmidt, A. Borodin, V. Mau, A. Spitsyn, S. Gubanov, K. Khubiev, A. Neshitov, T. Khudyakova O. Sukharev, A.Goluba, I. Baev. Strategy and management issues are considered in the works of V. Efremov, N. Kondratyev, P. Pokrytan, V. Shkardun, R. Fatkhutdinov, O. Vikhansky, R. Nureyev, F. Ufimtsev, R. Popov and others. Among the foreign scientists who study the issues of economic growth and strategic management, M. Porter, I. Schumpeter, D. Aaker, I. Ansoff, Jean Paul Blandinieres, D. Norton, M. Meskon, J.Keynes and P. Druckershould be called.

The general laws of development of economic systems that are applicable nowadays have been studied in the works of local and foreign economists, but the issues relating to the economic sustainability of enterprises in the conditions of modern Russian economy characterized by a heightened sensitivity to external and internal factors have not been highlighted properly.

The object of the research is the management process of drivers for economic sustainability of manufacturing enterprises in the conditions of changing external environment.

The goal of the article is to develop a model of managing drivers for economic sustainability in the modern state of the economic development.

\section{Materials and methods}

\section{A. Description of methods}

In this study, the basics of calculating economic sustainability of a manufacturing enterprise by integrating the indicators of economic growth, the economic balance of external and internal environment and economic sustainability of the manufacturing enterprise have been developed.

First of all it is required to use financial and economic analysis of the enterprise based on the index method to generate results that will characterize the state of the economic system and the economic growth of the enterprise. Under this analysis the information obtained by the survey of the employees as well as the data gained by questioning the managers is collected and processed.

Then it is required to create a model of the economic sustainability of the manufacturing enterprise. Based on the values obtained for each employee, an individual model of the economic sustainability of the manufacturing enterprise is created. Then, a group model and a general model of the economic sustainability of the manufacturing enterprise are created [17].

Based on these results some conclusions concerning the assessment of the economic sustainability are drawn, the effect of the each individual driver for the economic stability of the manufacturing enterprise is determined. Following these conclusions there is a search and analysis of the problems in the enterprise management. Reserves are determined to improve the economic sustainability of the manufacturing enterprise. Then some recommendations how to improve the economic sustainability of the manufacturing enterprise are prepared [10].

\section{B. Characterisics of the drivers for the enterprise economic sustainability perspective}

Economic sustainability is the internal state of an economic entity which is formed under the influence of plenty of factors.

Drivers for economic sustainability can be classified according to various criteria:

1. By the way of influence: stabilizing and destabilizing, i.e. having either a positive or a negative effect on the level of the economic sustainability of the enterprise.

2. By the place of occurrence: internal and external. Internal factors are created by the internal environment as a consequence of the enterprise performance as a whole or its employees' performance. External factors are created by the external environment without any participation and against the will of the company or its employees.

3. By the nature of exposure: direct and indirect. Direct factors have a direct impact on the level of economic sustainability of the enterprise. Indirect ones do not have a direct immediate impact on the level of sustainability, rather an indirect impact.

4. By the degree of dependence: objective and subjective. Objective factors are due to processes that develop independently or due to force majeure (e.g. natural disasters). Subjective factors are created deliberately by certain groups of people based on their interests.

In the most common form the economic sustainability of a manufacturing enterprise is determined by three major drivers:

1) economic growth as the determining factor;

2) economic balance (the state of internal and external environment of a manufacturing enterprise), it is the factor that ensures the proper functioning of all available enterprise subsystems;

3 ) the level of control that enables the full development of the enterprise in the course of its performance [13].

The perspective aims to maximize the growth of the economy, including the enterprise, with minimal deviation values of the economic system and / or the enterprise from the balance state. It is these two factors that are fundamental in building a model of economic sustainability, which is proposed to be used for the enterprise management and assessment of its performance.

\section{Graphic Model}

The basis of constructing a model of economic sustainability is a different combination of the abovementioned factors. These combinations can be divided into 4 groups: 
1) if the company is characterized by economic growth, while maintaining the state of balance, it is 'relative economic sustainability';

2) if the company is characterized by economic growth and the imbalance of its internal and external environment, it is 'critical economic sustainability';

3 ) if the company is not characterized by economic growth and at the same time there is the imbalance of its internal and external environment, then we can talk about the state of 'economic instability';

4) if the company is not characterized by economic growth, but it is in the state of balance of its internal and external environment, then this condition is called 'stagnation'.

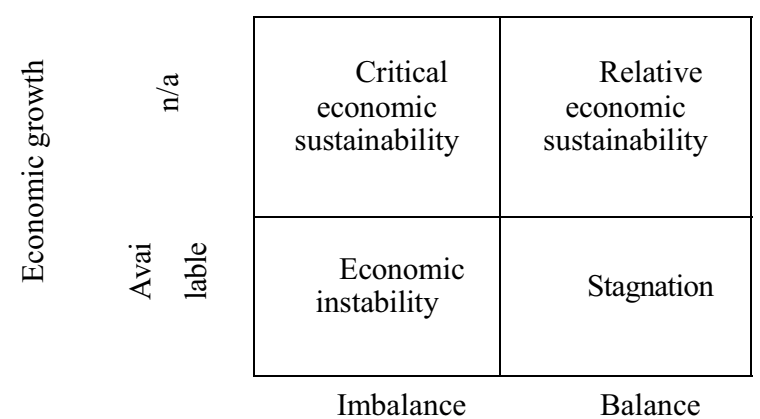

Fig.1. Model of Economic Sustainability.

The proposed model of economic sustainability can be used to improve the efficiency of company management, while rating companies by the indicator of economic sustainability and etc [5].

\section{Economic-mathematical model}

The assessment of economic sustainability is central to the management of the economic sustainability of an enterprise.

It should be noted that at the present time scientists and economists do not share the same opinion whether any specific indicators of the company should be considered as indicators of its economic sustainability. First of all, this is shown by a great variety of different approaches to the assessment of the economic sustainability of an enterprise under the current scientific methodology.

Today a lot of original approaches to the assessment of the sustainability of enterprises are offered. They are aimed at early detection of symptoms of performance worsening and potential bankruptcy. Diagnostic methods have been developed for more than 70 years, but even today they continue to attract the attention of analysts and remain the subject of scientific debate. The assessment of the economic stability of enterprises was deeply analyzed and a great progress in its methodology and means of implementation was noted especially in the last decade.

The economic-mathematical model presented in this study is based on the integration of the economic growth of the enterprise and its state.

The indicator of the economic growth of an enterprise is determined by the following formula:

$$
E_{i}=\sum_{j=1}^{n} y_{j}
$$

Where $y$ is a factor influencing the economic growth of an enterprise; $\mathrm{n}$ is a number of evaluated factors influencing the economic growth, $\mathrm{j}=1 \ldots \mathrm{n}$.

The value of the index of economic balance of an enterprise is determined similarly to create a model of economic sustainability $\left(\mathrm{E}_{\mathrm{i}}\right)$ :

$$
E_{i}=\sum_{t=1}^{m} x_{t}
$$

where $\mathrm{x}_{\mathrm{t}}$ is a factor influencing the economic balance of the enterprise; $\mathrm{m}$ is a number of evaluated factors affecting the economic balance, $\mathrm{t}=1 \ldots \mathrm{m}$.

An individual model of economic sustainability shown as a vector $\left(\mathrm{EM}_{\mathrm{i}}\right)$ is created on the basis of the obtained values:

$$
E M_{i}=\left(E_{i} ; E P_{i}\right)
$$

The indicator of group economic sustainability is figured out as follows $\left(\mathrm{EM}_{\mathrm{g}}\right)$ :

$$
E M_{g}=\sum_{i=1}^{p} E M_{i}
$$

where $p$ is a number of values in this group, $i=1 \ldots p$.

The indicator of general economic sustainability of a whole enterprise $\left(\mathrm{EM}_{\mathrm{o}}\right)$ is figured out by the formula:

$$
E M_{o} \sum_{g=1}^{k} E M_{g}
$$

where $\mathrm{k}$ is a number of groups under economic sustainability assessment, $\mathrm{g}=1 \ldots \mathrm{k}$.

\section{Conclusions}

Thus, the method of assessment of the economic sustainability of a manufacturing enterprise is an integrated approach to the assessment of the enterprise: analysis of all existing kinds of accounting and reporting combined into a single procedure with the study of the views of the employees and managers of the enterprise.

The management mechanism of the economic sustainability of a manufacturing enterprise implies some changes in the system of control and planning at a manufacturing enterprise in accordance with the identified shortcomings and reserves of its performance [16].

The economic policy of a manufacturing enterprise should aim to search for the optimal combination of the economic growth rate and the balance of the factors of external and internal environment of a manufacturing enterprise.

Management of the economic stability of a manufacturing enterprise by adjusting economic policy on the basis of identified shortcomings in its performance and untapped reserves is to achieve such a combination of methods of managerial decisions, which will ensure 
the effective performance of the manufacturing enterprise [19].

The integrated control mechanism of the economic sustainability of a manufacturing enterprise must include all of the functions of management and be based on the principles of continuity and coherence of actions.

The economic sustainability of an enterprise develops not only under the influence of any specific factors of external and internal environment, but also under the influence of unpredictable and difficult to predict factors of both economic and non-economic nature.

However, despite the availability of a large number of economic sustainability control mechanisms the problem of effective management of the economic sustainability of a manufacturing enterprise remains disputable and requires further improvement of existing and / or development of new effective approaches.

The current economic conditions do not encourage the domestic industry to strengthen; actually they hinder their sustainable development. But even in these difficult circumstances businesses must have the internal capacity and ability to adapt to the environmental influence, or economic sustainability.

The work was supported by Act 211 Government of the Russian Federation, contract № 02.A03.21.0011.

\section{References}

1. T.A. Khudyakova, A.V. Shmidt, Proc. of The 26th International Business Information Management Association Conference, 1626-1634 (2015)

2. T.A. Khudyakova, A.V. Shmidt, Mediterranean Journal of Social Sciences, 6, 4, 274-279 (2015)

3. T.A. Khudyakova, Actual problems of economics, 12, 444-450 (2015)

4. A.V. Shmidt, T.A. Khudyakova, Proc. of The 27th International Business Information Management Association Conference (2016)

5. A.V. Shmidt, T.A. Khudyakova, Proc. of The 27th International Business Information Management Association Conference (2016)

6. T.A. Khudyakova, A.V. Shmidt, Proc. of The 26th International Business Information Management Association Conference, 1607-1611 (2015)

7. V.P. Meshalkin, A.Y. Belozersky, Russian Entrepreneurship, 9(81), 92-95 (2006)
8. N.N. Dmitriev, Pulp, paper and cardboard, 7, 57-62 (2006)

9. Economy and ecology: mechanisms of interaction. http://bibliofond.ru/view.aspx?id=489159.

10. M.S. Abryutina, Financial management, 3, (2002)

11. E.I. Krylov, Analysis of financial state and investment attractiveness of an enterprise (Finance and Statistics, Moscow, 2003)

12. A.V. Grachev, Analysis and management of the financial stability of an enterprise (Finpress, Moscow, 2002)

13. N.N. Kreynina, Financial state of an enterprise: assessment methods (Business and Service, Moscow, 1997)

14. V.V. Kovalev, Financial analysis: methods and procedures (Finance and Statistics, Moscow, 2001)

15. I.A. Baev, V.I. Shiryaev, E.V. Shiryaev, Dynamical Theory of Firm: monograph (South Ural State University Publishing House, 2001)

16. R.Y. Loskutov, Reserves of improvement of economic sustainability of a manufacturing enterprise (Saratov, 1998)

17. I.V. Piskunova, Evolution of the interpretation of enterprise sustainability. http://ecsocman.hse.ru/data/2011 /05/20/1266918948/13.pdf.

18. D.M. Shotylo, The essence and content of the production system. http://ekportal.ru/page-id1785.html.

19. A.B. Borisov, Great Dictionary of Economics (Moscow, 2003)

20. V.I. Roshchin, Economic sustainability of enterprises and the implementation of their economic interests (Cheboksary, 2000). http://www.dissercat.com/ content ekonomicheskaya-ustoichivost-predpriyatii-irealizatsiya-ikh-ekonomicheskikh-interesov.

21. A.B. Oleinik, Enterprise economic sustainability in the modern conditions (Volgograd, 2002). www.dissercat.com/content/ekonomicheskayaustoichivost-predpriyatiya-v-sovremennykhusloviyakh.

22. T.A. Khudyakova, A.V. Shmidt, Proc. of The 26th International Business Information Management Association Conference, 1612-1616 (2015) 